Le Lait, 1986, 66 (3), 305-310

\title{
Improving the flavour acceptability of recombined milk blended with fresh milk
}

\author{
R.M. JOSHI, A.A. PATEL and B.N. MATHUR \\ Division of Dairy Technology, National Dairy Research Institute \\ Karnal 132001, India
}

\begin{abstract}
Summary
An evaluation of different means of improving the flavour acceptability of a 50:50 blend of recombined and fresh milks revealed that addition of sucrose $(0.2 \%)$, sodium citrate $(0.03 \%)$ or diacetyl $(0.25 \mathrm{ppm})$, or raising the solids-not-fat level to $10.0 \%$ were remarkably effective for this purpose. Replacement of $10 \%$ skimmilk powder used for the preparation of recombined milk, with sweet cream buttermilk powder was somewhat less effective. The improvement in the flavour of blended milk effected by sodium citrate and sodium chloride was also reflected, to a considerable extent, in the flavour of beverage tea whitened with the milk.
\end{abstract}

Key words : Recombined milk - Blended milk - Flavour - Additives.

\section{Résumé}

Amélioration de l'acceptabilité de la flaveur d'un mélange de lait recombiné et de lait frais

Différents moyens destinés à améliorer l'acceptabilité de la flaveur d'un mélange 50/50 de lait recombiné et de lait frais ont été évalués. Certains de ces moyens s'avéraient très efficaces : l'addition de sucrose $(0,2 \%)$, de citrate de sodium $(0,03 \%)$ ou de diacétyle $(0,25 \mathrm{ppm})$, ou encore l'élévation du taux d'extrait sec dégraissé à $10 \%$. Le remplacement de $10 \%$ de la poudre de lait écrémé utilisée pour la préparation du lait recombiné par de la poudre de babeurre de crème douce était un peu moins efficace. L'amélioration de flaveur obtenue grâce à l'ajout de citrate de sodium ou de chlorure de sodium se percevait également de façon significative dans du thé additionné de ce mélange de laits.

Mots clés : Lait recombiné - Mélange de laits - Flaveur - Additifs. 


\section{Introduction}

The recombination technology is of unique significance in making up regional and seasonal imbalances in demand and supply of milk on a global basis. However, in practice, it poses the problem of rather less acceptable flavour in comparison with fresh milk. It is recognized that using carefully prepared fresh raw materials, a recombined product fairly close to the fresh product can be obtained. Nevertheless, during transportation of the raw materials, anhydrous milkfat (AMF) in particular, to the place of recombination, certain changes take place in them which lead to a rather undesirable flavour in the end product (GunNIS, 1982; Slamet, 1982).

Owing to the flavour problem associated with it, recombined milk is generally blended with fresh milk, it thus serving as an extender of fresh milk rather than a substitute for it. According to SANDERSON (1970) about $50 \%$ recombined milk could be blended with fresh milk without greatly affecting the quality. Also, certain additives used in very small quantities or compositional modifications in the solids-not-fat (SNF) part of the product may be useful in enhancing the flavour acceptability of recombined milk (KIESEKER, 1975; NEwSTEAD et al., 1979). This paper presents the findings of a comparative assessment of various means of ameliorating the flavour of recombined milk prepared from the AMF transported from overseas, and blended with fresh milk $(50: 50)$.

\section{Raw materials}

\section{Materials and methods}

AMF (free fatty acids $0.42 \%$ as oleic acid, TBA value 0.89 and peroxide value 2.8 meq. $\mathrm{O}_{2} / \mathrm{kg}$ ) and spray-dried skim-milk powder (SMP) (moisture $4.6 \%$, titratable acidity $1.2 \%$ 1.a. and Solubility Index $0.5 \mathrm{ml}$ ) were obtained from Mother Dairy, Delhi. Butter milk powder (BMP) (moisture $6.4 \%$, titratable acidity $1.4 \%$ 1.a. and Solubility Index $0.8 \mathrm{ml}$ ) was manufactured from sweet cream buttermilk using an Anhydro (Denmark) spray dryer in the Experimental Dairy of the Institute.

\section{Recombined fresh milk blend}

Recombined milk (3.0\% fat and $8.5 \%$ SNF) was prepared by dispersing SMP in water, mixing it with melted AMF, homogenizing the mixture $\left(60^{\circ} \mathrm{C}\right.$, $\left.175 \mathrm{~kg} / \mathrm{cm}^{2}\right)$ and heating to $72^{\circ} \mathrm{C}$ immediately followed by cooling. It was blended with an equal amount of fresh pasteurized bulk milk of similar composition obtained from the Experimental Dairy. The blended milk was held at refrigeration temperature $\left(6-10^{\circ} \mathrm{C}\right)$ for $4-6$ hours before being used for sensory evaluation.

\section{Additives}

While the required quantities of trisodium citrate (IP/BP, Sarabhai Chemicals, India), sodium chloride (IP/BP, Sarabhai Chemicals) and commercial refined canesugar were dissolved in a small amount of distilled water before being 


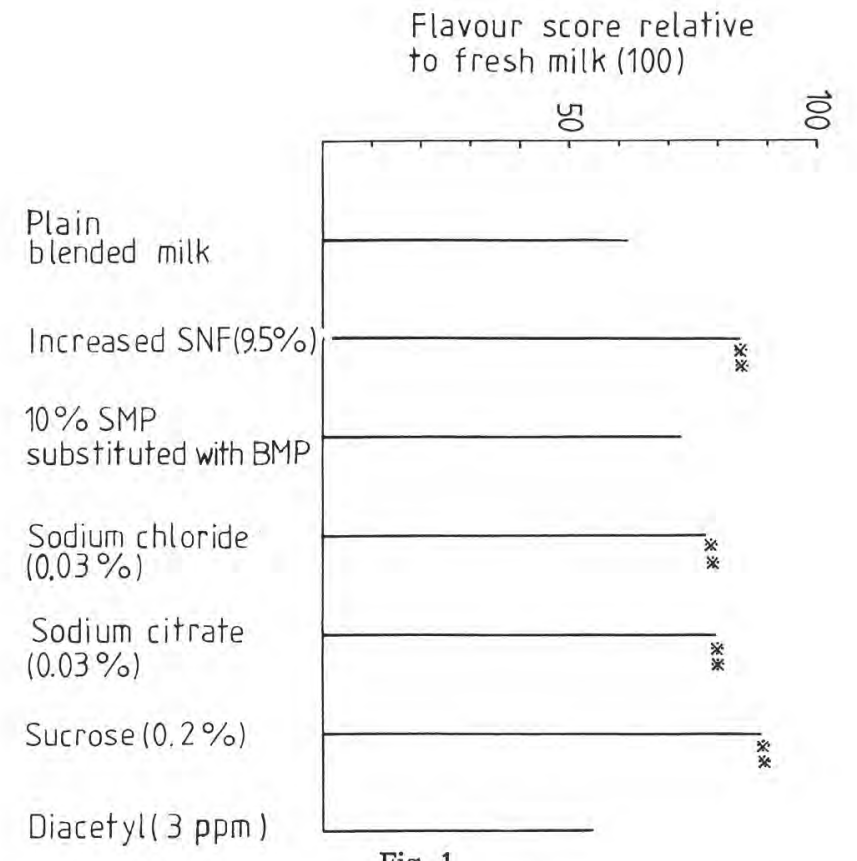

Fig. 1

A comparative assessment of different flavour-improving treatments for recombined-fresh milk blend. ** Significantly different from plain blended milk $(P<0.01$, critical difference $=13.5$ )

Comparaison de différents traitements destinés à améliorer la flaveur d'un mélange lait recombiné/lait frais. ** Différence significative à partir du mélange de départ $(P<0,01$, différence critique $=13,5$ ).

added to milk, diacetyl (Sigma Chemicals, USA) was added as a $0.01 \%$ solution in distilled water.

\section{Beverage tea}

The experimental milk samples were also examined for their influence on the flavour of beverage tea whitened with the milk. For this purpose, an extract was prepared by adding $1.3 \%$ (w/v) dry tea leaves ('Tajmahal', Brooke Bond, India) to boiling potable water and filtering the same. The hot extract was then mixed with milk in a ratio of $3: 1$ just before judging.

\section{Sensory evaluation}

The milk samples were subjected to sensory evaluation for flavour acceptability by a panel of eleven judges using a nine-point relative rating scale, fresh milk serving as a control. The mean scores were expressed relative to the fresh milk score (100). All evaluations were conducted in triplicates, preparing a separate lot of recombined milk for each replicate. Procedures prescribed by Indian Standard (1975) were followed for statistical analysis of sensory data. 


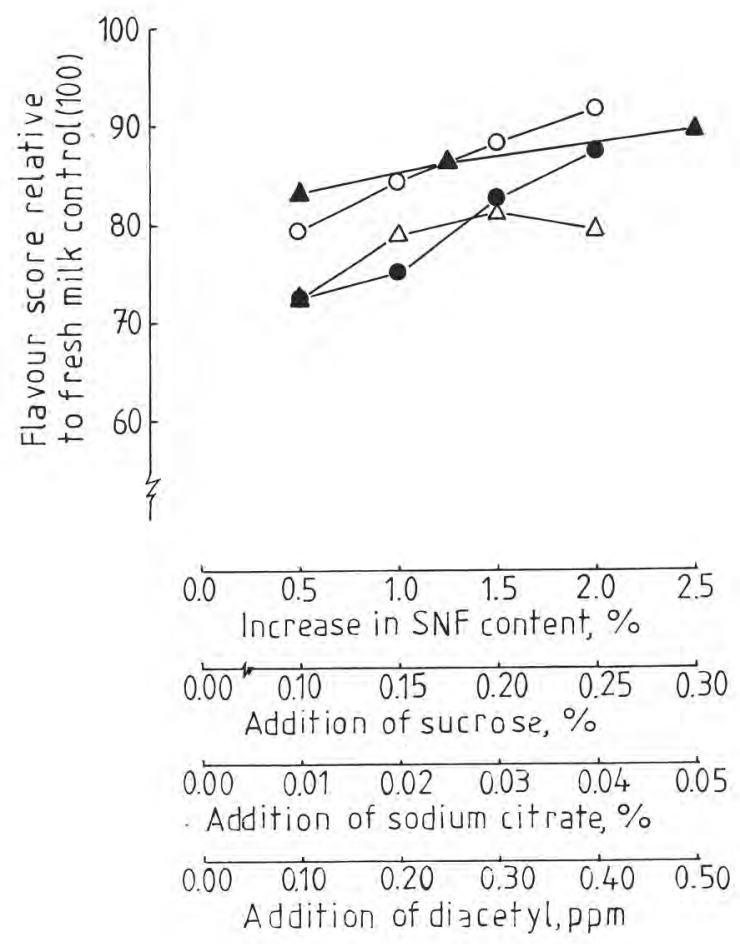

Fig. 2

Effect of selected treatments on the flavour acceptability of recombined-fresh milk blend. O SNF, - Sucrose, $\triangle$ Trisodium citrate, $\mathbf{\Delta}$ Diacetyl.

Effet des traitements sélectionnés sur l'acceptabilité de la flaveur du mélange lait recombinél lait frais. o Extrait sec dégraissé, - Sucrose, $\triangle$ Citrate de trisodium, $\Delta$ Diacétyle.

\section{Results and discussion}

It is a practical experience that the flavour of recombined milk made from transported or stored butterfat leaves much to be desired. As is evident from figure 1 , the recombined-fresh milk blend without any modification was flavourwise considerably less desirable than fresh milk alone. However, all the treatments studied, except diacetyl addition, improved the flavour acceptability of the milk. The improvement was statistically significant $(\mathrm{P}<0.01)$ with the exception of the use of BMP. The enhanced flavour score as a result of incorporation of the additives may be ascribed to their possible effect on perception of the flavour brought about by competitive blocking of taste receptors on the tongue as is generally the case with most flavour modifiers in foods (PlatTig, 1984). The flavour improving effect observed with increased SNF may on the other hand, be attributed to presumably reduced perception of the off-flavour originating from AMF because of increased adsorption of protein on fat globules (EL-Mot- 
TABLE I

\section{Flavour acceptability of beverage tea whitened by recombined and blended milks \\ Acceptabilité de la flaveur de thé additionné de lait recombiné ou de mélange de laits}

\begin{tabular}{l|c}
\hline \multicolumn{1}{c|}{ Type of milk used for whitening tea } & Flavour score* \\
\hline Fresh milk control & $100.0 \mathrm{a}$ \\
Recombined milk & $52.3 \mathrm{~b}$ \\
Blended milk (50:50) & $70.8 \mathrm{c}$ \\
Blended milk + 0.03\% trisodium citrate & $83.5^{\mathrm{d}}$ \\
Blended milk + 0.03\% sodium chloride & $83.5 \mathrm{~d}$ \\
& \\
\hline Means with different superscripts differ significantly $(\mathrm{P}<0.01) ;$ critical dif- \\
\hline
\end{tabular}

TALEB et al., 1982). The relative ineffectiveness of the use of BMP for partial replacement of SMP was to some extent in agreement with TAMSMA et al. (1967), The diacetyl-added milk had a pronounced 'culture-like' flavour, which made it rather unacceptable at the 3 ppm level.

The three treatments found most effective among all examined above, viz., increase in the SNF content, addition of sodium citrate and sucrose as additives were further studied individually at different levels so as to establish optimum levels of incorporation. Diacetyl at levels lower than the one used previously was also included. As shown in figure 2, the flavour scores increased significantly $(\mathrm{P}<0.01)$ with increasing levels of SNF, sucrose and diacetyl. However, the flavour scores at the highest levels of these modifiers i.e. $10.5 \% \mathrm{SNF}, 0.25 \%$ sucrose and $0.5 \mathrm{ppm}$ diacetyl, were only marginally and not significantly $(\mathrm{P}>0.05)$ greater than those at the next lower levels i.e. $10.0 \%, 0.20 \%$ and $0.25 \mathrm{ppm}$ respectively, which in themselves represented a significant improvement. Addition of sodium citrate beyond $0.03 \%$ caused a small decline in the flavour score although the milk was still substantially more desirable than plain milk.

The flavour of beverage tea may be influenced by the flavour of the whitening agent depending on the amount of the latter used. The off-flavour of recombinde milk used as a whitener is particularly liable to show up in tea. Data presented in table 1 indicate that the tea whitened by recombined milk as well as blended milk was flavourwise considerably less desirable. It was further observed that sodium citrate or sodium chloride $(0.03 \%)$ added to the blended milk significantly $(\mathrm{P}<0.01$ ) retarded the off-flavour of milk perceived in the tea. However, the flavour acceptability of beverage tea prepared from the modified milk was still decidedly lower than that of fresh milk tea. Moreover, the flavour advantage 
of additive incorporation was sligthly less when the milk was used as a tea whitener than when consumed as such.

\section{Conclusion}

It is evidenced by this investigation that the off-flavour of recombined milk resulting from the use the of transported or stored milkfat or butteroil could be reduced to a notable extent and the milk blended with fresh milk could be made substantially more acceptable by adding $0.2 \%$ sucrose, $0.25 \mathrm{ppm}$ diacetyl or $0.03 \%$ sodium citrate, or by increasing the SNF content by $1.5 \%$. Use of buttermilk powder to replace $10 \%$ of skimmilk powder was not significantly beneficial. The flavour improving effect of sodium citrate and sodium chloride $(0.03 \%)$ was also reflected, though to a slightly less extent, in the beverage tea whitened with the milk.

Increasing the SNF level to $10.0 \%$ would seem a distinct possibility towards making recombined milk or its blend with fresh milk more acceptable but only at an increased cost. The additives mentioned above are generally not permitted in market milk. Nevertheless, in the light of present investigation they deserve serious legal consideration in respect of recombined milk particularly in countries where this type of milk constitutes a sizeable portion of total city milk supplies.

ThanKs are due to Dr. I.S. Verma, Director, N.D.R.I., Karnal for his keen interest in this work.

Reçu le 19-8-1985.

Accepté pour publication le 16-11-1985

\section{References}

El-Mottaleb A., Saleem R.M., Hasan A.K., 1982. Composition of globule membranes as affected by fat source and solids concentration. 21st Intern. Dairy Congr., Moscow, 1 (2), 154 .

GunNIS L.F., 1982. Recombination of milk and milk products. Sem. Proc., IDF Bull, $142,56$.

Indian StANDARd, 1975. Guide for Sensory Evaluation of Foods. III. Statistical Analysis of Data. IS 6273 (Part III), 1975. Indian Standard Institution, New Delhi.

KIESEKER F.G., 1975. The reconstitution and recombination of conserved products for extending milk supply for liquid consumption. Milk Ind., 76, 1149-1151.

Newstead D.F., Goldmann A., Zadow J.G., 1979. Recombined milks and creams. Monograph on Recombination of Milk and Milk Products. IDF Bull., 116, 7-13.

Plattig K.H., 1984. The sense of taste. In : Sensory Analysis of Foods edited by Piggot J.R., Elsevier Alppied Science Publ. Ltd., London, 1-22.

SANDERSON W.B., 1970. Reconstituted and recombined dairy products. N.Z. J. Dairy Sci. Technol., 5, 139-143.

SLAMET D.S., 1982. Some practical problems in the manufacture and distribution of sweetened condensed milk. In : Recombination of Milk and Milk Products. IDF Bull., 142, 68.

Tamsma A., Kurtz F.E., Berlin E., Pallanch M.J., 1967. Flavour of recombined milk. J. Dairy Sci., 50, 1878-1881. 